\title{
Expression of gamma-aminobutyric acid receptors on neoplastic growth and prediction of prognosis in non-small cell lung cancer
}

Xiaoxue Zhang ${ }^{1,2}$, Rong Zhang ${ }^{2}$, Yuanjie Zheng ${ }^{2}$, Jianfei Shen ${ }^{2}$, Dakai Xiao ${ }^{2}$, Jin Li ${ }^{2}$, Xiaoshun Shi ${ }^{2}$ Liyan Huang ${ }^{2}$, Hailing Tang ${ }^{2}$, Jun Liu' ${ }^{2}$ Jianxing $\mathrm{He}^{2^{*}}$ and Haibo Zhang ${ }^{2,3}$

\begin{abstract}
Background: Gamma-aminobutyric acid (GABA) is the main inhibitory neurotransmitter in the adult mammalian brain, but exerts physiologic effects other than that on neurotransmitter in non-neuronal peripheral tissues and organs. GABA may affect cancer growth through activation GABA receptors. We investigated the gene expression of GABA receptors in tissue of non-small cell lung cancers (NSCLC) and non-cancerous tissues, and found that the gene expression of GABA receptor phenotypes was correlated with tumorigenesis and clinical prognosis.

Methods: Sixty-one snap-frozen human samples of NSCLC tissues and paired non-cancerous tissues $(5 \mathrm{~cm}$ away from tumor) were analyzed. Gene expression of GABA receptors was detected by Real-time quantitative PCR (RT-qPCR). Survival times in relation to the expression of GABA receptor phenotypes were analyzed. Human NSCLC cell lines H1299, A549, H520, H460 and human bronchial epithelial cell line BEAS-2B were used to determine the phenotypes of GABA inhibitory effects on cancer cell growth. The effects of exogenous administration of GABA on H1299 cell growth were examined.

Results: The gene expressions were significantly higher in NSCLC tissues than in the paired non-cancerous tissues for $G_{A B A_{A}}$ receptor subunit a3 $\left(G A B R_{A 3}, P=0.030\right)$; for $G A B A_{A}$ receptor subunit epsilon $\left(G A B R_{E}, P=0.036\right)$; and $G_{A B A_{B}}$ receptor subunit $2\left(G_{A B B R}, P=0.005\right)$. Kaplan-Meier curves showed that patients with high expression of $G_{A B B R_{2}}$ gene and low expression of $G A B R_{A 3}$ gene had a better prognosis $(P<0.05)$. The administration of GABA resulted in suppressed proliferation of NSCLC cell lines in a dose- and time-dependent manner. The use of the GABA receptor antagonist CGP35348 could reverse the inhibitory effect.

Conclusions: The pattern of GABA receptor gene phenotype expression may be involved in the regulation of tumorigenesis. A high expression of $\mathrm{GABBR}_{2}$ with a low expression of $\mathrm{GABR}_{\mathrm{A} 3}$ may predict a better outcome. The treatment with GABA attenuates cancer cell growth in vitro. The expression of GABA receptor may be not only promising genetic therapeutic targets but may also serve as valuable prognostic markers for NSCLC.
\end{abstract}

Keywords: Gamma aminobutyric acid receptor, Survival, Biomarker, Prognosis

\footnotetext{
*Correspondence: hejx@vip.163.com

${ }^{2}$ Guangzhou Research Institute of Respiratory Disease \& China State Key Laboratory of Respiratory Disease, The First Affiliated Hospital of Guangzhou Medical College, Guangzhou, Guangdong Province 510120, China Full list of author information is available at the end of the article
} 


\section{Background}

Cancer is a major global public health problem. One in 4 deaths in the United States is due to cancer [1]. Lung cancer is comprising $17 \%$ of the total new cancer cases and $23 \%$ of the total cancer deaths [2]. Non-small cell lung cancer (NSCLC) accounts for about $80 \%$ of all lung cancer cases where adenocarcinoma is dominantly presented [3]. Conventional treatment of NSCLC has improved survival, but the 5 -year survival rate is approximately $16 \%$ over the past 30 years [1]. Novel and effective methods are urgently required for lung cancer therapy.

Gamma-aminobutyric acid (GABA) is the main inhibitory neurotransmitter in the adult mammalian brain via activation of specific GABA receptors highly expressed in the central nervous system (CNS) [4,5]. GABA receptors are composed of $\mathrm{GABA}_{\mathrm{A}}$ and $\mathrm{GABA}_{\mathrm{B}}$ receptors. $\mathrm{GABA}_{\mathrm{A}}$ receptors are ligand-gated chloride channels composed of five subunits. These subunits are encoded by 19 different genes that have been grouped into eight subclasses based on sequence homology $(\alpha 1-6, \beta 1-3, \gamma 1-3, \delta, \varepsilon, \theta, \pi, \rho 1-3)$. $\mathrm{GABA}_{\mathrm{B}}$ receptors are heterodimeric G-protein-coupled receptors (GPCRs) composed of $\mathrm{GABBR}_{1}$ and $\mathrm{GABBR}_{2}$ subunits which are both required for normal receptor functioning [6].

It has recently revealed that GABA and its receptors also exist in non-neuronal peripheral tissues and organs, indicating that GABA exerts physiologic effects other than the inhibitory neurotransmitter property. In fact, GABA has been shown to be involved in the development of many tissues and organs, including the peripheral nervous system [7], the development of the palate [8], lung [9], pancreas [10], digestive tract [11], liver [12], chondrocytes [13], testicular cells [14] and even stem cells [15].

Given that GABA participates in the proliferation of various normal cell types and tissues, it is intriguing to consider the potential function of GABA in cancer cells. Recent studies gave the evidences that GABA and its receptors seemed to play critically regulative effects on many kinds of cancers [12,16-31]. In most cases, the levels of GABA receptors accompanying other growth signaling components had significant changes in cancer cells. This raised the possibility that manipulating GABA receptor activity might inhibit tumor growth [25].

In this study, we tested the hypothesis that GABA receptor profiles modulate cancer survival. We thus investigated the gene expression of GABA receptor phenotypes in NSCLC tissues and paired non-cancerous tissues obtained from surgical patients to correlate the GABA receptor gene profiles with clinical outcome. To examine the specific effects of GABA receptor on lung cancer cell growth, we investigated the GABA receptor profiles in cancer cell lines and in normal human epithelial cell line in the presence and absence of exogenous administration of GABA.

\section{Methods}

\section{Cancer cell lines}

Human NSCLC cell lines H1299(adenocarcinoma), A549

(adenocarcinoma), H520(squamous cell carcinoma), H460 (large cell carcinoma) and normal human bronchial epithelial cell line BEAS-2B (ATCC, Rockville, Maryland) were cultured at $37^{\circ} \mathrm{C}$ with $5 \% \mathrm{CO}_{2}$ in DMEM (Gibco, Beijing, China) supplemented with 10\% FBS (Gibco, Beijing, China) without antibiotics.

\section{MTT assays for cell proliferation}

To measure the proliferation of cells, the colorimetric 3(4, 5-dimethyle thiazol-2-yl)-2, 5-diphenyl tetrazolium bromide (MTT) assays (Sigma) were used in vitro. In the MTT assays, cells were seeded into 96-well plates $\left(2 \times 10^{3}\right.$ cells per well), grown overnight, washed in PBS, and incubated with GABA (Sigma-Aldrich) at $0.1 \mu \mathrm{mol} / \mathrm{L}$ to 500 $\mu \mathrm{mol} / \mathrm{L}$ in the presence or absence of $100 \mu \mathrm{mol} / \mathrm{L}$ picrotoxin (PTX, $\mathrm{GABA}_{\mathrm{A}}$ receptor antagonist) or CGP35348 (CGP, GABA $A_{B}$ receptor antagonist), respectively. MTT was then added (10ug/well) for 4 h. Formazan products were solubilized with DMSO, and the optical density was measured at $490 \mathrm{~nm}$.

\section{Tissues and subjects}

Sixty-one samples of NSCLC tissues and paired noncancerous tissues ( $5 \mathrm{~cm}$ away from tumor) were collected from the Thoracic Cardio Surgery Department of the First Affiliated Hospital of Guangzhou Medical College under full ethical clearance by the Guangzhou Medical College Ethics Committee for experimentation on human subjects. Informed written consent was obtained from the participants. All subjects were Chinese. The collected samples were immediately cut into small pieces and snap-frozen in liquid nitrogen until further use. All tumor tissue and paired non-cancerous tissue samples were pathologically confirmed.

\section{RNA extraction and CDNA synthesis}

Total RNA from cell lines and liquid-nitrogen-frozen NSCLC tissue samples were extracted using Trizol reagent (Invitrogen). First-strand cDNAs were synthesized using primerscript RT reagent kit (Takara). Briefly, a mix of 2 ug RNA, $2 \mu \mathrm{l}$ of $5 \times$ gDNA eraser buffer and $1 \mu \mathrm{l}$ of gDNA eraser in a final volume of $10 \mu \mathrm{l}$ with RNase free $\mathrm{DH}_{2} \mathrm{O}$, was incubated at $42^{\circ} \mathrm{C}$ for $2 \mathrm{~min}$ to get rid of gDNA, and placed on ice for at least $1 \mathrm{~min}$. Then $4 \mu \mathrm{L} 5 \times$ Primerscript buffer, $1 \mu \mathrm{L}$ Primerscript RT enzyme mix I, $1 \mu \mathrm{L}$ RT primer mix, and $3 \mu \mathrm{L}$ RNase free $\mathrm{DH}_{2} \mathrm{O}$ were added, and incubated at $37^{\circ} \mathrm{C}$ for $15 \mathrm{~min}$ followed by $85^{\circ} \mathrm{C}$ for $5 \mathrm{sec}$. The cDNA samples were stored at $-20^{\circ} \mathrm{C}$ until use. 


\section{Primer design}

Primers were designed using Primer Premier 5.0 and oligo 7 Software. Each primer pair was verified for gene specificity using Nucleotide Basic Local Alignment Search Tool from the GenBank non-redundant nucleotide sequence database (National Centre for Biotechnology Information, 2009, http://www.ncbi.nlm.nih.gov/). The sequence of each primer pair and the expected amplicon size were summarised in Table 1.

\section{PCR}

PCR was performed to pick out the genes expression in NSCLC cancer cell lines using Premix Taq version 2.0 kit (Takara). The reaction condition was followed: initial denaturation at $95^{\circ} \mathrm{C}$ for $1 \mathrm{~min} ; 35 \mathrm{cycles}$ of $30 \mathrm{sec}$ at $95^{\circ} \mathrm{C}$; $30 \mathrm{sec}$ at $58^{\circ} \mathrm{C}$; and $30 \mathrm{sec}$ at $72^{\circ} \mathrm{C}$; followed by a final 3 min extension at $72^{\circ} \mathrm{C}$. $3 \%$ Agarose gel was used in electrophoresis to separate the reaction products at $80 \mathrm{~V}$, 40min. After dyeing with ethidium bromide, the Gel Doc ${ }^{\mathrm{tw}}$ EZ Imager (BIO-RAD) was used for imaging.

\section{RT-qPCR}

Real-time quantitative PCR was carried out in tissues cDNA samples using the $\mathrm{SYBR}^{\circ}$ Premix Ex Taq ${ }^{\text {Tix }}$ reagent kit (Takara) through ABI PRISM ${ }^{\circ} 7900$ HT Fast Real-Time PCR system (Applied Biosystems). Briefly, $2 \mu$ of each cDNA product was amplified in a mixture containing 12.5 $\mu \mathrm{l}$ of $2 \times \mathrm{SYBR}^{\circ}$ Premix Ex Taq ${ }^{\mathrm{Tw}}, 0.5 \mu \mathrm{l}$ of $10 \mu \mathrm{mol} / \mathrm{L}$ PCR sense primer and the same quantitative antisense primer with $\mathrm{dH}_{2} \mathrm{O}$ in a final volume of $25 \mu \mathrm{L}$. The RT-qPCR was performed using the following parameters: initial denaturation at $95^{\circ} \mathrm{C}$ for $30 \mathrm{sec}, 40$ cycles of $5 \mathrm{~s}$ at $95^{\circ} \mathrm{C}, 30 \mathrm{~s}$ at $60^{\circ} \mathrm{C}$. The dissolved curve was added to verify the specificity of amplified products. Wells with no template were included for each primer set as a negative control. In each experiment, samples were amplified in duplicate for each of the genes of interest and the reference gene. Only average CT values with a standard deviation $<0.5$ were accepted.

\section{Statistic analysis}

The expression of each gene of interest was determined in relation to the reference gene $18 \mathrm{~S}$ rRNA. The difference in the mean CT values of the duplicate samples against the reference gene was calculated to give the $\Delta C T$. The relative quantitation value was then expressed as two times $-\Delta \mathrm{CT}\left(2^{-\Delta \mathrm{CT}}\right)$. Analysis of the $2^{-\Delta \mathrm{CT}}$ values data was performed using SPSS 13.0 followed by Paired-Samples $t$ Test and Independent-Samples $t$ Test where appropriate. Correlation analysis was carried out for GABA concentration and cell growth over time. Survival times between groups were displayed by Kaplan-Meier curves after a logrank test. $P<0.05$ was considered statistical significance.

\section{Results}

\section{Effect of GABA on cancer cell proliferation}

To examine the effects of administration of exogenous GABA on cancer cells proliferation in vitro, MTT assays were performed on the $\mathrm{H} 1299$ cells at broad range of concentrations of GABA $(0.1-500 \mu \mathrm{mol} / \mathrm{L})$. There was a dose- and time-dependent inhibition of cell proliferation with GABA (Figure 1A, B). The GABA concentration used was negatively correlated with the proliferation index (Figure $1 \mathrm{C}, \mathrm{r}=-0.778, \mathrm{p}<0.001$; Figure $1 \mathrm{D}, \mathrm{r}=-0.876$, $\mathrm{p}<0.001$ ). This inhibitory effects of GABA on cell proliferation was blocked by the use of $C G P, a G A B A_{B}$ receptor antagonist, while PTX, a $\mathrm{GABA}_{\mathrm{A}}$ receptor antagonist, had no effect (Figure 1E, F). Similar results were observed in

Table 1 Primer sequences, NCBI gene ID and amplicon size

\begin{tabular}{|c|c|c|c|c|}
\hline Gene & NCBI gene ID & & Sequence $\left(5^{\prime}-3^{\prime}\right)$ & Amplicon size (bp) \\
\hline \multirow[t]{2}{*}{$\mathrm{GABR}_{\mathrm{A3}}$} & 2556 & Sense & CCGTCTGTTATGCCTITGTATT & 165 \\
\hline & & Antisense & TGTTGAAGGTAGTGCTGGTIT & \\
\hline \multirow[t]{2}{*}{$\mathrm{GABR}_{\mathrm{B} 3}$} & 2562 & Sense & GGAGATACCCCCTGGACGAGCA & 196 \\
\hline & & Antisense & GGATAGGCACCTGTGGCGAAGA & \\
\hline \multirow[t]{2}{*}{$\mathrm{GABR}_{\mathrm{E}}$} & 2564 & Sense & ATGCTTCTCCTAAACTCCGCC & 248 \\
\hline & & Antisense & CTTAAAACGCTTGCACCACTC & \\
\hline \multirow[t]{2}{*}{ GABRp } & 2568 & Sense & CGACCGTGTTATCAATGACC & 120 \\
\hline & & Antisense & CCCCAAACACAAAGCTAAAGCA & \\
\hline \multirow[t]{2}{*}{$\mathrm{GABBR}_{1}$} & 2550 & Sense & CAGATAAATGGATTGGAGGGT & 101 \\
\hline & & Antisense & GAGAACTGAGACGGAGATAAAGAG & \\
\hline \multirow[t]{2}{*}{$\mathrm{GABBR}_{2}$} & 9568 & Sense & GAGTCCACGCCATCTTCAAAAAT & 108 \\
\hline & & Antisense & TCAGGATACACAGGTCGATCAGC & \\
\hline \multirow[t]{2}{*}{$18 \mathrm{~S}$ rRNA } & 100008588 & Sense & GCAATTATTCCCCATGAACG & 123 \\
\hline & & Antisense & GGCCTCACTAAACCATCCAA & \\
\hline
\end{tabular}




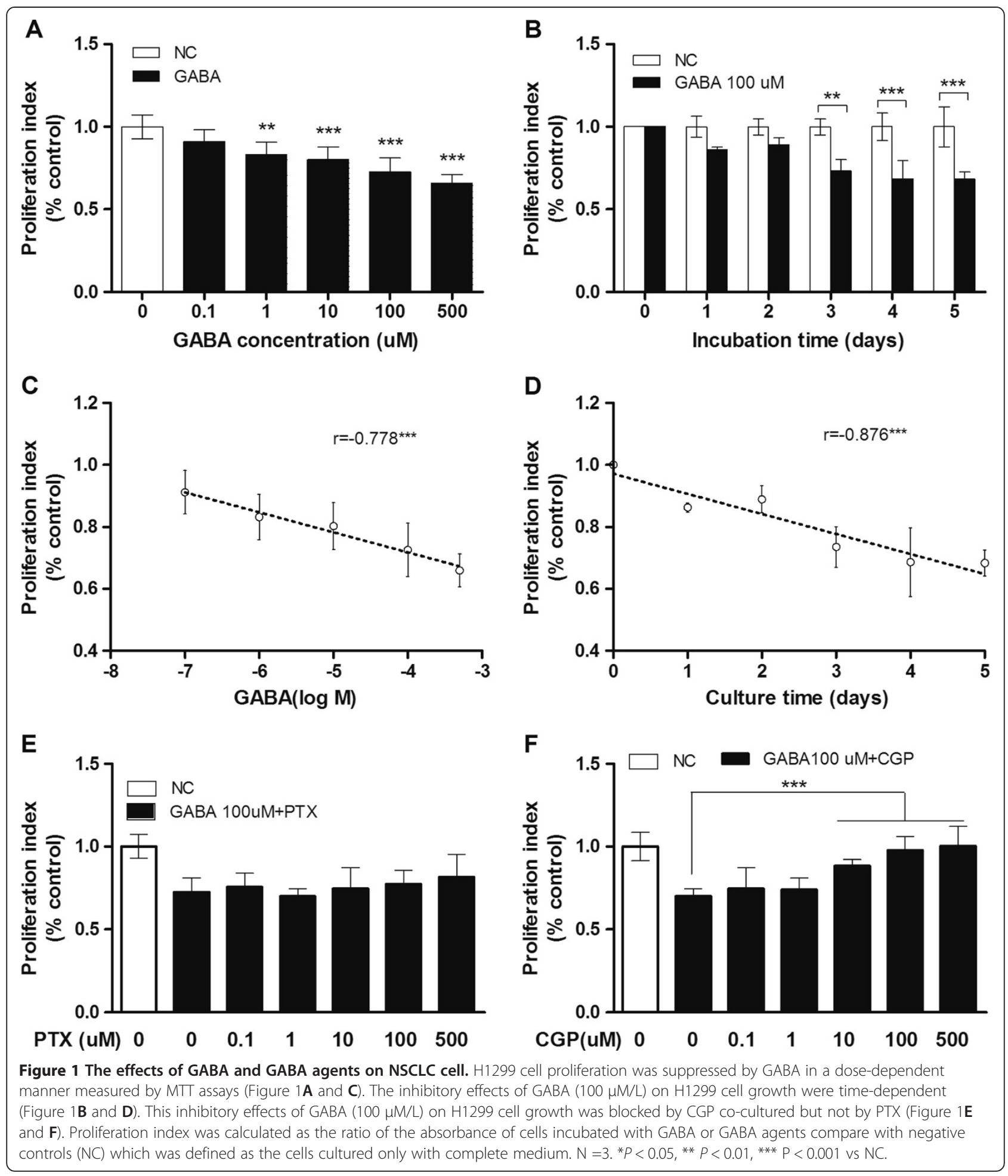

other NSCLC cell lines, such as A549, H520, H460 (data not show).

GABA receptor profiles in NSCLC cell lines

The mRNA profile of GABA receptors was determined in NSCLC cell lines including H1299, A549, H520,
H460 and BEAS-2B. The mRNA of human brain (a kind gift from Dr. He Junde, Department of neurosurgery in the same affiliation as ZX) was used as positive control and the normal lung bronchiolial epithelial cells BEAS-2B served as negative control. We found that six GABA receptor subunits were expressed in most NSCLC cell lines 


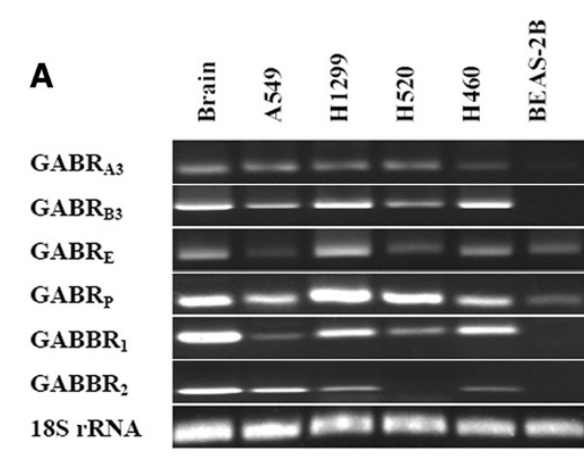

B GABR $_{\text {A3 }}$

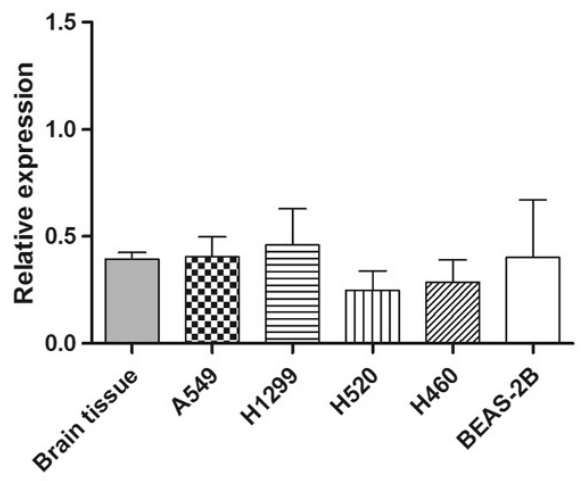

GABR $_{\mathrm{E}}$

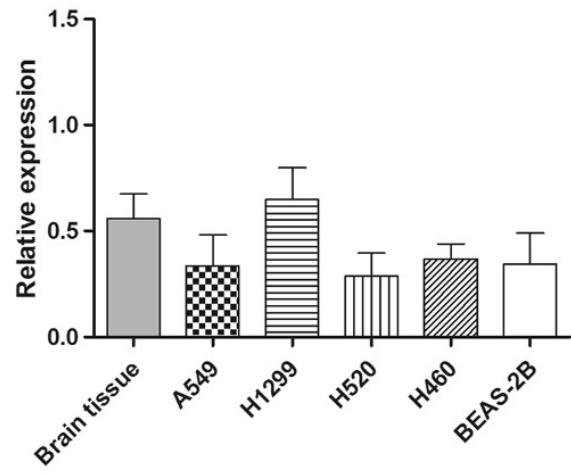

GABBR $_{1}$

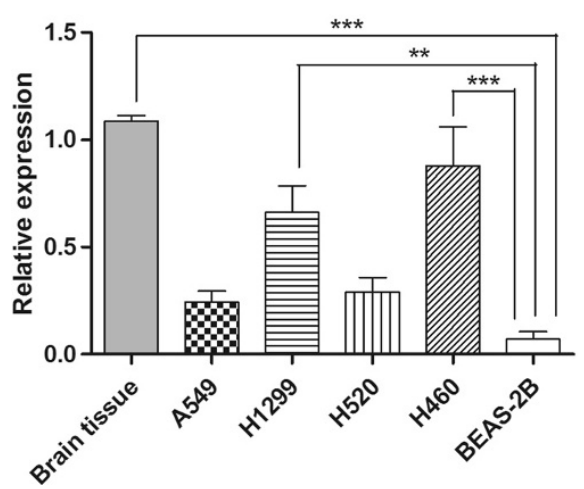

$\mathrm{GABR}_{\mathrm{B} 3}$

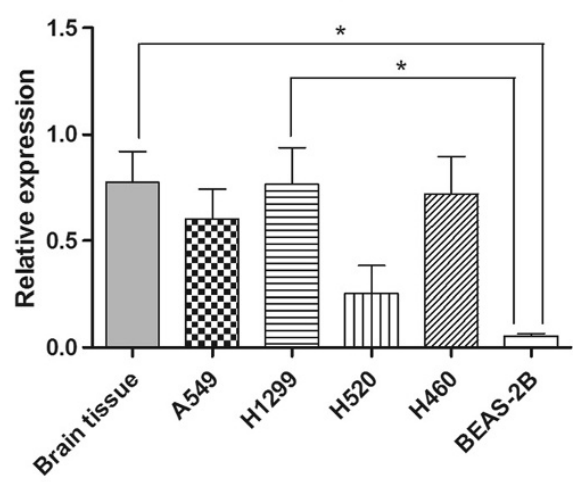

GABR $_{\mathbf{p}}$

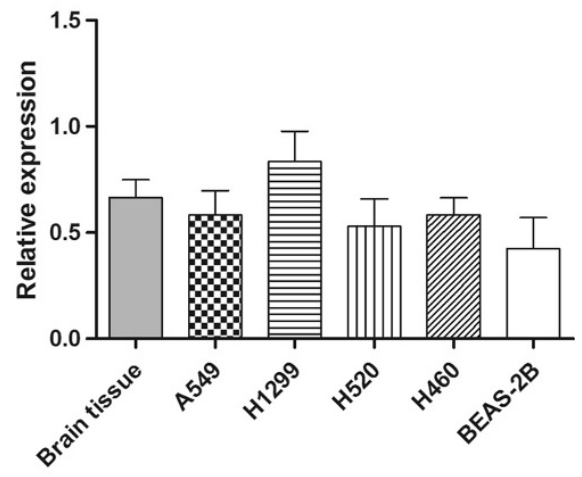

GABBR $_{2}$

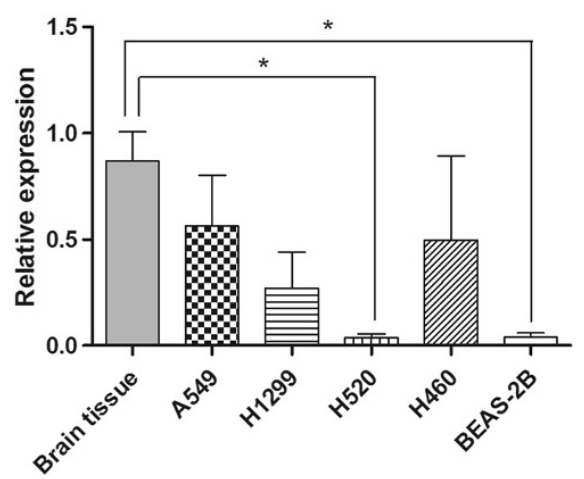

Figure 2 (See legend on next page.) 
(See figure on previous page.)

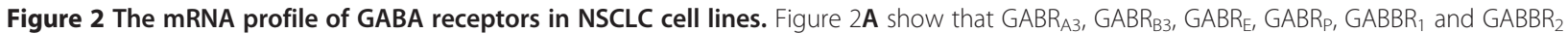
ecpress in NSCLC cell lines. Brain expression acts as a positive control and BEAS-2B as a negative control. Figure $2 \mathbf{B}$ show three times of the PCR for gene relative expression. ${ }^{*} P<0.05,{ }^{* *} P<0.01$.

including $\mathrm{GABA}_{\mathrm{A}}$ receptor subunits $\left(\mathrm{GABR}_{\mathrm{A} 3}, \mathrm{GABR}_{\mathrm{B} 3}\right.$, $\left.\mathrm{GABR}_{\mathrm{E}}, \mathrm{GABR}_{\mathrm{P}}\right)$ and $\mathrm{GABA}_{\mathrm{B}}$ receptor subunits $\left(\mathrm{GABBR}_{1}\right.$ and $\mathrm{GABBR}_{2}$ ) (Figure $2 \mathrm{~A}$ and $\mathrm{B}$ ).

\section{GABA receptor profiles in NSCLC tissues and paired non-} cancerous tissues

The gene expression of $\mathrm{GABR}_{\mathrm{A} 3}, \mathrm{GABR}_{\mathrm{E}}$ and $\mathrm{GABBR}_{2}$ was significantly higher in primary NSCLC tissues than in the paired non-cancerous tissues $\left(\mathrm{GABR}_{\mathrm{A} 3}, t=2.227, P=0.030\right.$; $\mathrm{GABR}_{\mathrm{E}}, t=2.148, P=0.036 \mathrm{GABBR}_{2}, t=2.928, P=0.005$; Figure $3 \mathrm{~A}, \mathrm{~B}$ and $\mathrm{C}$ ). There was no significant difference observed in the expression of $\operatorname{GABR}_{\mathrm{B} 3}(t=-0.330$, $P=0.742), \mathrm{GABR}_{\mathrm{P}}(t=1.072, P=0.288)$ or $\mathrm{GABBR}_{1}$ $(t=-0.326, P=0.746$, Figure $3 \mathrm{D}, \mathrm{E}$ and $\mathrm{F})$ in the same tissues examined (Table 2).

\section{Survival analysis in relation to GABA receptor gene profiles}

Using the median of $2^{-\Delta C T}$ value as cutoff point, the data was divided into high and low expression for analysis. A high expression of $\mathrm{GABBR}_{2}$ in the lung tissue was associated with better survival as compared to those where low expression was detected (Figure 4B). However, a higher expression of $\mathrm{GABR}_{\mathrm{A} 3}$ was associated with a lower survival rate (Figure 4A). Smoking and TNM stage were also the important influential factors of decreased survival (Figure 4E, F). Expression of $\mathrm{GABR}_{\mathrm{E}}$ and pathological grade did not appear to influence on survival time (Figure 4C, D).

\section{GABA receptors profiles and selected clinical characteristics}

The gene expression of $\mathrm{GABR}_{\mathrm{A} 3}$ was significantly higher in the NSCLC tissues in male patients, while the expression of $\mathrm{GABBR}_{2}$ was significantly higher than paired controls in the patients of female (Table 3). It appeared that the gene expression of both $\mathrm{GABR}_{\mathrm{A} 3}$ and $\mathrm{GABBR}_{2}$ was higher in the patients with early stage of pathology, but not in the advanced stages.

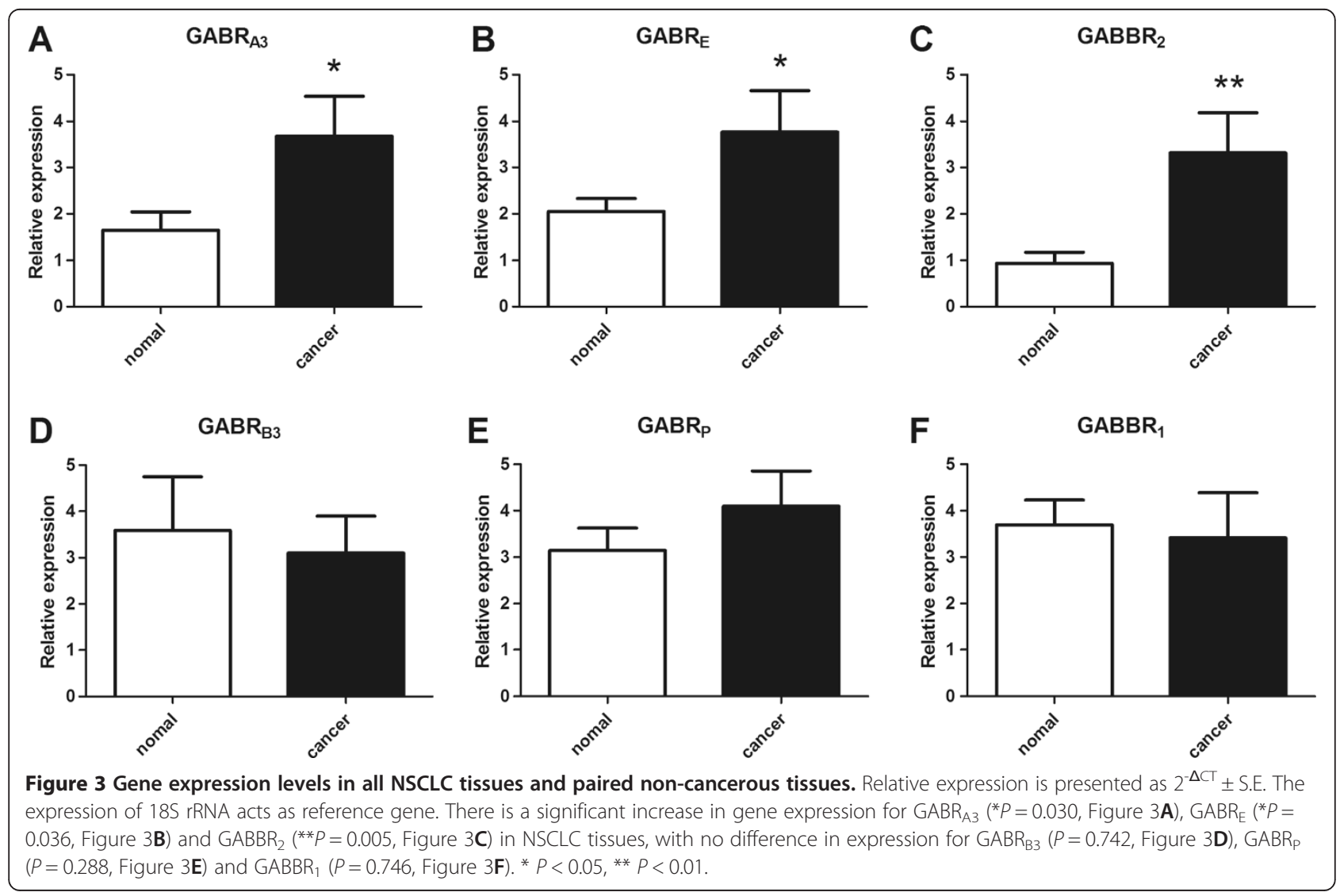


Table 2 Comparison of GABA receptor gene relative expression between cancer and paired non-cancerous tissue

\begin{tabular}{llll}
\hline & Normal $(\mathbf{n}=\mathbf{6 1})$ & Cancer $(\mathbf{n}=\mathbf{6 1})$ & $\boldsymbol{P}$ value \\
\hline GABR $_{A 3}$ & $1.647 \pm 0.394$ & $3.681 \pm 0.853$ & $0.030^{*}$ \\
GABR $_{E}$ & $2.054 \pm 0.276$ & $3.767 \pm 0.883$ & $0.036^{*}$ \\
GABBR $_{2}$ & $0.940 \pm 0.236$ & $3.315 \pm 0.868$ & $0.005^{* *}$ \\
GABR $_{B 3}$ & $3.585 \pm 1.163$ & $3.103 \pm 0.792$ & 0.742 \\
GABRP $_{P}$ & $3.147 \pm 0.475$ & $4.095 \pm 0.760$ & 0.288 \\
GABBR $_{1}$ & $3.693 \pm 0.538$ & $3.413 \pm 0.976$ & 0.746 \\
\hline
\end{tabular}

The data of GABA receptor gene relative expression were expressed as mean \pm SE. Normal: Paired non-cancerous tissue. ${ }^{*} P<0.05$, ${ }^{*} P<0.01$.

\section{Discussion}

GABA and GABA receptors act as an inhibitory neurotransmitter in the mature CNS, but their functions in non-neuronal cells or tumor cells are not well addressed. Previous investigation has reported that GABA is significantly decreased in NSCLC tissues [26]. The previous observation maybe explained by our current findings demonstrating that GABA exerts inhibitory effects on human NSCLC cell. Our results further demonstrate that $\mathrm{GABA}_{\mathrm{B}}$ receptors play an important role in mediating the GABA-inhibitory effects on NSCLC cells since the effects were blocked by using the antagonist CGP35348 specific for $\mathrm{GABA}_{\mathrm{B}}$ receptor. Decreased GABA level might have resulted in impaired inhibitory effects on cancer cell proliferation as seen clinically [26]. A compensatory mechanism may be required by enhancing the expression of $\mathrm{GABA}_{\mathrm{B}}$ receptors in order to redeem the impaired inhibitory effects.

The etiological factors of lung cancer are still not clear, but the tumor progression is associated with genetic changes and is reflected in phenotypic changes such as altered gene expression profiles. In this study, we found that the six genes of GABA receptors are expressed in most of NSCLC cells and tissues, including $\mathrm{GABR}_{\mathrm{A} 3}$, $\mathrm{GABR}_{\mathrm{B} 3}, \mathrm{GABR}_{\mathrm{E}}, \mathrm{GABR}_{\mathrm{B}} \mathrm{GABBR}_{1}$ and $\mathrm{GABBR}_{2}$. These subunits might compose functional $\mathrm{GABA}_{\mathrm{A}}$ and $\mathrm{GABA}_{\mathrm{B}}$ receptor. These genetic changes suggest that GABA receptors have close relationship with NSCLC progression.

As for $\mathrm{GABA}_{\mathrm{B}}$ receptors, it is now well accepted that $\mathrm{GABA}_{\mathrm{B}}$ receptors assemble into heteromers composed of one $G_{A B B R}$ and one $G_{A B B R}$ subunit, which are both required for normal receptor function [6,32]. Some recent reports have suggested that GABA inhibits neoplastic proliferation via $G_{A B A}$ receptor $[23,26]$. Since $G_{A B A_{B}}$ receptor could strongly inhibit base level and isoproterenol-induced cAMP, $\mathrm{p}$-CREB, cyclic adenosine monophosphate response element-luciferase activity and p-extracellular regulated kinase-1 (ERK1)/2 and effectively blocked DNA synthesis and cell migration. The inhibitory cancer cells arrest in $G(0) / G(1)$ phase which is associated with down-regulation of intracellular cAMP level [33]. In our study, GABA inhibited proliferation of NSCLC cells in a dose-dependent and a time-dependent manner. This inhibitory effect could be blocked in the presence of $\mathrm{GABA}_{\mathrm{B}}$ receptor inhibitor CGP35348. However, co-cultured with $\mathrm{GABA}_{\mathrm{A}}$ receptor inhibitor picrotoxin, there were no significant proliferative effects on cancer cells versus control. These results imply that GABA inhibition of NSCLC cell proliferation was associated with $\mathrm{GABA}_{\mathrm{B}}$ receptor which coincides with the report by Schuller and Al-Wadei $[23,26]$. The high level expression of $\mathrm{GABA}_{B}$ receptor gene in NSCLC tissues compared with the adjacent non-tumor lung tissues, implicated that GABA and $\mathrm{GABA}_{B}$ receptor pathways could be a critical factor in regulation of NSCLC cells proliferation. This pathway might be a promising molecular target for the development of new therapeutic strategies for antineoplaston.

As for $\mathrm{GABA}_{\mathrm{A}}$ receptors, it has been demonstrated that $\mathrm{GABA}_{\mathrm{A}}$ receptors are usually composed of two $\alpha$ subunits, two $\beta$ subunits, and one $\gamma$ subunit, and sometime the $\gamma$ subunit is replaced by other subunits, such as $\delta, \varepsilon, \pi$ and $\theta$ [34]. Different $\mathrm{GABA}_{\mathrm{A}}$ receptor subunits have been detected in many cancer cell lines and tissues. Li et al. [12] detected overexpression of $\mathrm{GABR}_{\mathrm{Q}}$ in hepatocellular carcinoma cell line HepG2, and half of the tested hepatocellular carcinoma tissues. Takehara [35] identified the overexpression of GABA receptor pi subunit $\left(G_{A B R}\right)$ in PDAC cells. In gastric cancer, more than five $\mathrm{GABA}_{\mathrm{A}}$ receptor subunits were associated with stimulating KATO III cells [28]. The similar results that $\mathrm{GABA}_{\mathrm{A}}$ receptors are related to cancer cell proliferation were reported in prostate cancer [29], breast carcinoma [36], even in normal human small airway epithelial cells [37]. These findings imply that the inward $\mathrm{Cl}^{-}$ionic current transport and the activated mitogen-activated protein kinase/extracellular signal-regulated kinase (MAPK/Erk) cascade via $\mathrm{GABA}_{\mathrm{A}}$ receptors positively promotes cell proliferation. Our study revealed that the $\mathrm{GABR}_{\mathrm{A} 3}$ receptor gene was overexpression in NSCLC tissues compare with paired non-cancerous tissues, this was consistent with the study reported by Liu et al. [38]. In addition, beside overexpression of $\mathrm{GABR}_{\mathrm{A} 3}$ and $\mathrm{GABR}_{\mathrm{E}}$ genes, the other $\mathrm{GABA}_{\mathrm{A}}$ receptor genes expression in our study including $G_{A B R_{B}}$ and $\mathrm{GABR}_{\mathrm{P}}$ were also detected in lung cancers, although there was no significant difference between NSCLC tissues and paired non-cancerous tissues. These $\mathrm{GABA}_{\mathrm{A}}$ receptor subunits may form a functional pentameric chloride channel. We observe that the overexpression $\mathrm{GABR}_{\mathrm{A} 3}$ and $G_{A B R}$ genes were not associated with proliferative effects on cancer cells. This indecipherable phenomenon will lend us to take more investigations of their roles in lung cancers.

Furthermore, our clinical data analysis showed that both $\mathrm{GABA}_{\mathrm{A}}$ receptors $\left(\mathrm{GABR}_{\mathrm{A} 3}\right)$ and $\mathrm{GABA}_{\mathrm{B}}$ receptor $\left(G A B B R_{2}\right)$ genes were significantly expressed in the early 


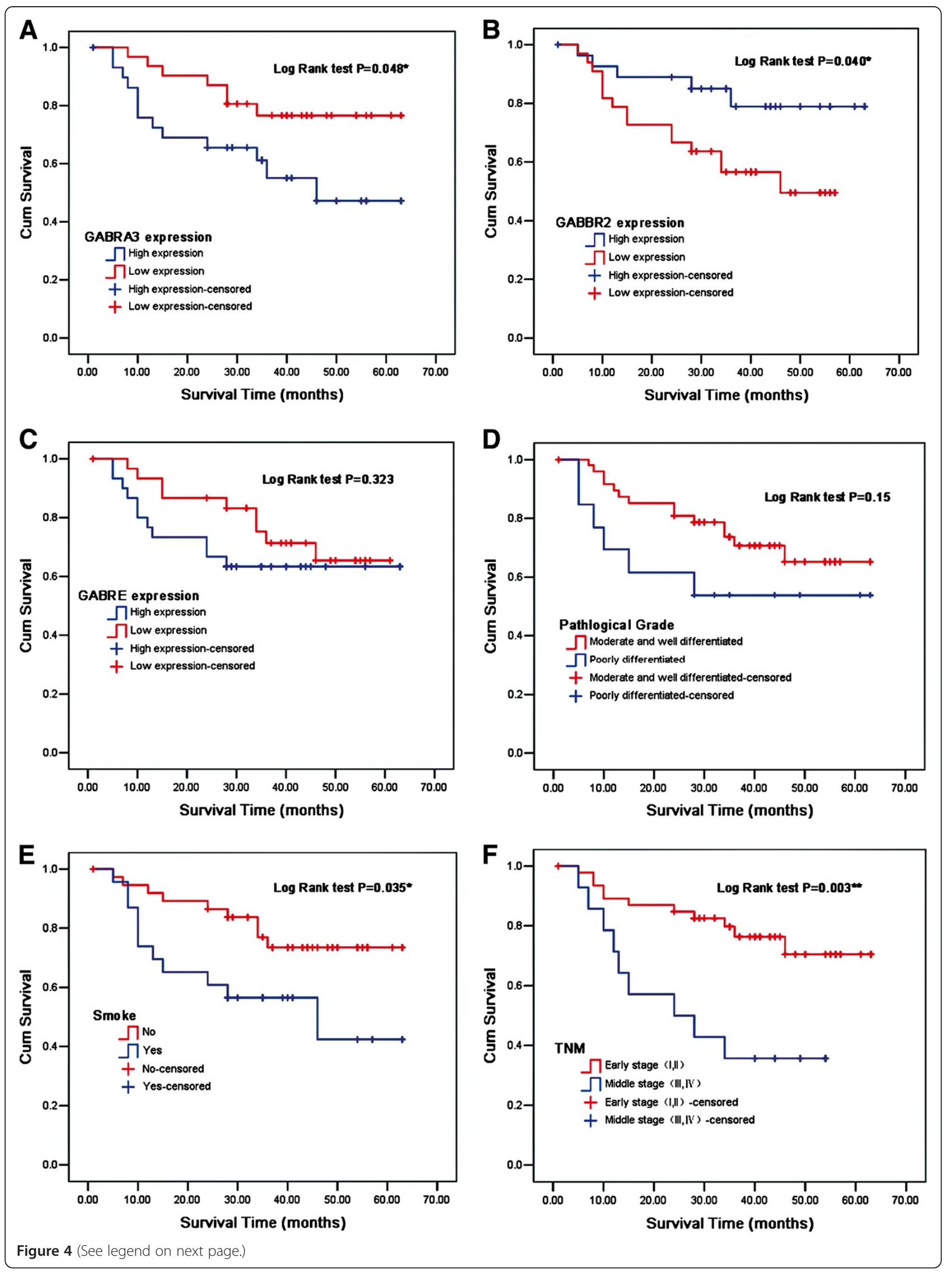


(See figure on previous page.)

Figure 4 Kaplan-Meier survival curves of NSCLC patients based on various influential factors. Figure $4 A$, Overall survival rate in patients with high expression of $\mathrm{GABR}_{\mathrm{A} 3}$ was significantly lower than that in patients with high expression. Figure $4 \mathbf{B}$, Overall survival rate in patients with high expression of $\mathrm{GABBR}_{2}$ was significantly higher than that in patients with low expression. Figure $\mathbf{4 E}$, $\mathbf{F}$, the smokers and the patients in advanced stage had a shorter survival time. Figure $4 \mathbf{C}, \mathbf{D}$, In spite of curve separated, GABR and pathological grade seemed to have no influence on survival time. ${ }^{*} P<0.05,{ }^{* *} P<0.01$.

pathological stage (stage I and II) of the lung cancer patients, and the expression was gone in stage III and IV. This suggests that high level of gene expression of these GABA receptors may be critical in inhibition of early stage of cancer cells and this regulatory effect got impaired in advanced stage. We speculate that therapeutic intervention approaches that enhance GABA receptors maybe beneficial in late stages of NSCLC patients.

We observe a correlation between the high expression of $\mathrm{GABBR}_{2}$ gene and the greater survival rate in patients with NSCLC. The overexpression of $\mathrm{GABBR}_{2}$ gene was mostly seen in female patients who had better outcome. This suggests that patients with higher level $\mathrm{GABBR}_{2}$ might have better outcome. This observation is consistent

Table 3 GABRA3, GABRE and GABBR2 gene expression in NSCLC tissues compare with paired non-cancerous tissues

\begin{tabular}{lcccc}
\hline Variable & $\mathrm{N}(\%)$ & \multicolumn{3}{c}{$\boldsymbol{P}$ value } \\
\cline { 3 - 5 } & & $\mathrm{GABR}_{\mathrm{A3}}$ & $\mathrm{GABR}_{\mathrm{E}}$ & $\mathrm{GABBR}_{2}$ \\
\hline Total & $61(100)$ & $0.030^{*}$ & $0.036^{*}$ & $0.005^{* *}$
\end{tabular}

Gender

Male

Female

Age

$<60$

$>60$

Smoking history

Yes

No

Histotype

\section{Adenocarcinoma}

Squamous cell carcinoma

Pathological Grade

$$
\text { I, II }
$$

III

Pathological Stage

\begin{tabular}{llllc} 
I, II & $47(77)$ & $0.050^{*}$ & NS & $0.008^{* *}$ \\
III & $9(15)$ & NS & NS & NS \\
IV & $5(8)$ & NS & NS & NS \\
\hline
\end{tabular}

Pathological grade I: well differentiation, grade II: moderately differentiation, grade III: poorly differentiation. Pathological stage refers to the 7th Edition of TNM Classification of Malignant Tumors form UICC. $P$-value represents the gene expression of GABA receptor in NSCLC tissues compared with that in paired non-cancerous controls. NS: no significant difference. ${ }^{*} P<0.05$, ** $P<0.01$. with previous in vitro data showing that high level GABBR $_{2}$ gene expression is associated with inhibition of cancer cell proliferation $[26,39,40]$.

In contrast, high level $\mathrm{GABR}_{\mathrm{A} 3}$ gene expression is correlated with cancer cell development $[12,35,41]$, and thus these patients had worse outcome. We indeed showed that the higher gene expression of $\mathrm{GABR}_{\mathrm{A} 3}$ was mostly detected in those male patients who had a worse prognosis.

Our data was based on a relatively small sample size of 61 patients with NSCLC who were followed for 3-5 years. Our data suggests that the gene expression of certain GABA receptor subunits may be useful for prediction of NSCLC prognosis. We believe that a longer term followup study with larger sample size would be required to confirm our current findings.

\section{Conclusion}

The present study has identified significant gene profiles of GABA receptors in NSCLC and the gene profiles are correlated with patients' survival. Exogenous administration of GABA can inhibit NSCLC growth by activation on GABA receptors. Our data suggests that GABA receptors can modulate cancer cell proliferation and their gene profiles may be able to help predict prognosis in patients with NSCLC.

\section{Competing interests}

The authors declare they have no competing interests of this article.

\section{Authors' contributions}

ZXX participated in all experiments and drafted the manuscript; ZR participated in the RT-qPCR assays; ZYJ, SJF, LJ, SXS, HLY, THL, and LJ carried out collection of the NSCLC tissue, RNA extraction and clinical data analysis; XDK took part in the statistical analysis; HJX participated in the study design; ZHB initiated the study design, participated in data analysis and manuscript writing. All authors read and approved the final manuscript.

\section{Acknowledgments}

The authors thank Mo Lili for valuable help with preparation of the tissue samples and all members in He Jianxing's lab for their technical assistance.

\section{Author details}

'Guangdong Cardiovascular Institute, Southern Medical University, Guangzhou 510080 Guangdong Province, China. ${ }^{2}$ Guangzhou Research Institute of Respiratory Disease \& China State Key Laboratory of Respiratory Disease, The First Affiliated Hospital of Guangzhou Medical College, Guangzhou, Guangdong Province 510120, China. ${ }^{3}$ Departments of Anesthesia, Medicine and Physiology, University of Toronto, Toronto Ontario M5B 1W8, Canada. 


\section{References}

1. Siegel R, Naishadham D, Jemal A: Cancer statistics, 2012. CA Cancer J Clin 2012, 62:10-29.

2. Jemal A, Bray F, Center MM, Ferlay J, Ward E, Forman D: Global cancer statistics. CA Cancer J Clin 2011, 61:69-90.

3. Custodio A, Mendez M, Provencio M: Targeted therapies for advanced non-small-cell lung cancer: current status and future implications. Cancer Treat Rev 2012, 38:36-53.

4. Sieghart W: Structure and pharmacology of gamma-aminobutyric acidA receptor subtypes. Pharmacol Rev 1995, 47:181-234.

5. Kerr DI, Ong J: GABAB receptors. Pharmacol Ther 1995, 67:187-246.

6. Bettler B, Kaupmann K, Mosbacher J, Gassmann M: Molecular structure and physiological functions of GABA(B) receptors. Physiol Rev 2004, 84:835-867.

7. Magnaghi V, Ballabio M, Cavarretta IT, Froestl W, Lambert JJ, Zucchi I, Melcangi RC: GABAB receptors in Schwann cells influence proliferation and myelin protein expression. Eur J Neurosci 2004, 19:2641-2649.

8. Ding R, Tsunekawa N, Obata K: Cleft palate by picrotoxin or 3-MP and palatal shelf elevation in GABA-deficient mice. Neurotoxicol Teratol 2004, 26:587-592.

9. Jin N, Guo Y, Sun P, Bell A, Chintagari NR, Bhaskaran M, Rains K, Baviskar P, Chen Z, Weng T, Liu L: lonotropic GABA receptor expression in the lung during development. Gene Expr Patterns 2008, 8:397-403.

10. Soltani N, Qiu H, Aleksic M, Glinka Y, Zhao F, Liu R, Li Y, Zhang N, Chakrabarti $\mathrm{R}, \mathrm{Ng} \mathrm{T}$, et al: GABA exerts protective and regenerative effects on islet beta cells and reverses diabetes. Proc Natl Acad Sci USA 2011, 108:11692-11697.

11. Wang FY, Watanabe M, Zhu RM, Maemura K: Characteristic expression of gamma-aminobutyric acid and glutamate decarboxylase in rat jejunum and its relation to differentiation of epithelial cells. World J Gastroenterol 2004, 10:3608-3611.

12. Li YH, LiU Y, Li YD, Liu YH, Li F, Ju Q, Xie PL, Li GC: GABA stimulates human hepatocellular carcinoma growth through overexpressed GABAA receptor theta subunit. World J Gastroenterol 2012, 18:2704-2711.

13. Tamayama T, Maemura K, Kanbara K, Hayasaki H, Yabumoto Y, Yuasa M, Watanabe M: Expression of $\mathrm{GABA}(\mathrm{A})$ and $\mathrm{GABA}(\mathrm{B})$ receptors in rat growth plate chondrocytes: activation of the GABA receptors promotes proliferation of mouse chondrogenic ATDC5 cells. Mol Cell Biochem 2005, 273:117-126.

14. Kanbara K, Okamoto K, Nomura S, Kaneko T, Shigemoto R, Azuma H, Katsuoka Y, Watanabe M: Cellular localization of GABA and GABAB receptor subunit proteins during spermiogenesis in rat testis. $J$ Androl 2005, 26:485-493.

15. Andang M, Hjerling-Leffler J, Moliner A, Lundgren TK, Castelo-Branco G, Nanou E, Pozas E, Bryja V, Halliez S, Nishimaru H, et al: Histone $\mathrm{H} 2 \mathrm{AX}$-dependent $\mathrm{GABA}(\mathrm{A})$ receptor regulation of stem cell proliferation. Nature 2008, 451:460-464.

16. Lukasiewicz PD, Shields $C R$ : A diversity of GABA receptors in the retina Semin Cell Dev Biol 1998, 9:293-299.

17. Watanabe M, Maemura K, Kanbara K, Tamayama T, Hayasaki H: GABA and GABA receptors in the central nervous system and other organs. Int Rev Cytol 2002, 213:1-47.

18. Azuma H, Inamoto $T$, Sakamoto T, Kiyama S, Ubai T, Shinohara $Y$, Maemura K, Tsuji M, Segawa N, Masuda H, et al: Gamma-aminobutyric acid as a promoting factor of cancer metastasis; induction of matrix metalloproteinase production is potentially its underlying mechanism. Cancer Res 2003, 63:8090-8096.

19. Thaker PH, Yokoi K, Jennings NB, Li Y, Rebhun RB, Rousseau DL Jr, Fan D, Sood AK: Inhibition of experimental colon cancer metastasis by the GABA-receptor agonist nembutal. Cancer Biol Ther 2005, 4:753-758.

20. Watanabe M, Maemura K, Oki K, Shiraishi N, Shibayama Y, Katsu K: Gamma-aminobutyric acid (GABA) and cell proliferation: focus on cancer cells. Histol Histopathol 2006, 21:1135-1141.

21. Rotondo A, Serio R, Mule F: Functional evidence for different roles of GABAA and GABAB receptors in modulating mouse gastric tone. Neuropharmacology 2010, 58:1033-1037.

22. Al-Wadei HA, Ullah MF, Al-Wadei M: GABA (gamma-aminobutyric acid), a non-protein amino acid counters the beta-adrenergic cascade-activated oncogenic signaling in pancreatic cancer: a review of experimental evidence. Mol Nutr Food Res 2011, 55:1745-1758.
23. Al-Wadei HA, Al-Wadei MH, Schuller HM: Cooperative regulation of non-small cell lung carcinoma by nicotinic and beta-adrenergic receptors: a novel target for intervention. PLoS One 2012, 7:e29915.

24. Schuller HM, Al-Wadei HA: Neurotransmitter receptors as central regulators of pancreatic cancer. Future Oncol 2010, 6:221-228.

25. Young SZ, Bordey A: GABA's control of stem and cancer cell proliferation in adult neural and peripheral niches. Physiology (Bethesda) 2009, 24:171-185.

26. Schuller HM, AI-Wadei HA, Majidi M: Gamma-aminobutyric acid, a potential tumor suppressor for small airway-derived lung adenocarcinoma. Carcinogenesis 2008, 29:1979-1985.

27. Roberts SS, Mendonca-Torres MC, Jensen K, Francis GL, Vasko V: GABA receptor expression in benign and malignant thyroid tumors. Pathol Oncol Res 2009, 15:645-650.

28. Maemura K, Shiraishi N, Sakagami K, Kawakami K, Inoue T, Murano M, Watanabe M, Otsuki Y: Proliferative effects of gamma-aminobutyric acid on the gastric cancer cell line are associated with extracellular signal-regulated kinase 1/2 activation. J Gastroenterol Hepatol 2009, 24:688-696.

29. Abdul M, McCray SD, Hoosein NM: Expression of gamma-aminobutyric acid receptor (subtype A) in prostate cancer. Acta Oncol 2008, 47:1546-1550.

30. D'Urso PI, D'Urso OF, Storelli C, Mallardo M, Gianfreda CD, Montinaro A, Cimmino A, Pietro C: Marsigliante S: miR-155 is up-regulated in primary and secondary glioblastoma and promotes tumour growth by inhibiting GABA receptors. Int J Oncol 2012, 41:228-234.

31. Von Metzler A, Nitsch C: [Effects of 3-methylcholanthrene and 3-methylcholanthrene plus piracetam on the gamma-amino-butyric acid (GABA) content of several cerebral regions (author's transl)]. J Cancer Res Clin Oncol 1981, 101:339-343.

32. Pinard $A$, Seddik $R$, Bettler $B$ : GABAB receptors: physiological functions and mechanisms of diversity. Adv Pharmacol 2010, 58:231-255.

33. Wang T, Huang W, Chen F: Baclofen, a GABAB receptor agonist, inhibits human hepatocellular carcinoma cell growth in vitro and in vivo. Life Sci 2008, 82:536-541.

34. Olsen RW, Sieghart W: GABA A receptors: subtypes provide diversity of function and pharmacology. Neuropharmacology 2009, 56:141-148.

35. Takehara A, Hosokawa M, Eguchi H, Ohigashi H, Ishikawa O, Nakamura $Y$, Nakagawa H: Gamma-aminobutyric acid (GABA) stimulates pancreatic cancer growth through overexpressing GABAA receptor pi subunit. Cancer Res 2007, 67:9704-9712.

36. Drell TL, Joseph J, Lang K, Niggemann B, Zaenker KS, Entschladen F: Effects of neurotransmitters on the chemokinesis and chemotaxis of MDA-MB -468 human breast carcinoma cells. Breast Cancer Res Trea 2003, 80:63-70.

37. Xiang YY, Wang S, Liu M, Hirota JA, Li J, Ju W, Fan Y, Kelly MM, Ye B, Orser $B$, et al: A GABAergic system in airway epithelium is essential for mucus overproduction in asthma. Nat Med 2007, 13:862-867.

38. Liu Y, Guo F, Dai M, Wang D, Tong Y, Huang J, Hu J, Li G: Gammaaminobutyric acid A receptor alpha 3 subunit is overexpressed in lung cancer. Pathol Oncol Res 2009, 15:351-358.

39. Lodewyks C, Rodriguez J, Yan J, Lerner B, Lipschitz J, Nfon C, Rempel JD, Uhanova J, Minuk GY: GABA-B receptor activation inhibits the in vitro migration of malignant hepatocytes. Can J Physiol Pharmacol 2011, 89:393-400.

40. Schuller HM, Al-Wadei HA, Majidi M: GABA B receptor is a novel drug target for pancreatic cancer. Cancer 2008, 112:767-778.

41. Liu Y, Li YH, Guo FJ, Wang JJ, Sun RL, Hu JY, Li GC: Gamma-aminobutyric acid promotes human hepatocellular carcinoma growth through overexpressed gamma-aminobutyric acid A receptor alpha 3 subunit. World J Gastroenterol 2008, 14:7175-7182.

doi:10.1186/1479-5876-11-102

Cite this article as: Zhang et al:: Expression of gamma-aminobutyric acid receptors on neoplastic growth and prediction of prognosis in nonsmall cell lung cancer. Journal of Translational Medicine 2013 11:102. 